\title{
Autocrine and Paracrine Effects of Atrial Natriuretic Peptide Gene Transfer on Vascular Smooth Muscle and Endothelial Cellular Growth
}

\author{
Ryuichi Morishita, Gary H. Gibbons, Richard E. Pratt, Naruya Tomita, ${ }^{\ddagger}$ Yasufumi Kaneda, ${ }^{\star}$ Toshio Ogihara, ${ }^{\ddagger}$ \\ and Victor J. Dzau \\ Division of Cardiovascular Medicine, Falk Cardiovascular Research Center, Stanford University School of Medicine, Stanford, \\ California 94035; *Institute for Cellular and Molecular Biology, and ${ }^{\ddagger}$ Department of Geriatric Medicine, Osaka University Medical \\ School, Osaka, Japan
}

\section{Abstract}

In addition to the atria, recent evidence suggests that atrial natriuretic peptide (ANP) is also synthesized in other tissues. Of particular interest is the location of ANP mRNA in the vessel wall. We and others have shown that exogenously added ANP inhibited the growth of endothelial cells and vascular smooth muscle cells (VSMC) in culture. However, it is not known if the locally synthesized ANP would act similarly. Because cultured endothelial cells and VSMC have lost the ability to express the endogenous ANP gene, we have transfected cells in culture with an expression vector expressing rat ANP and have examined the effects on growth.

Cultured endothelial cells transfected with an ANP expression vector synthesized and secreted high levels of ANP. These cells also showed significantly lower rates of DNA synthesis under basal and fibroblast growth factor (FGF)stimulated conditions. Addition of conditioned medium from endothelial cells transfected with ANP vector to nontransfected endothelial cells resulted in the significant increase in cyclic GMP. Similarly, conditioned media collected from endothelial cells transfected with ANP vector also decreased DNA synthesis in VSMC. Coculture of ANPtransfected endothelial cells with quiescent VSMC showed that released ANP from endothelial cells inhibited DNA synthesis in VSMC. Finally, we examined the autocrine effect of direct transfection of ANP vector into VSMC. Transfection of the ANP vector decreased DNA synthesis in VSMC under basal and angiotensin II-stimulated conditions. Similarly, transfection of the ANP vector resulted in a decrease in the PDGF and serum (5\%)-stimulated DNA synthesis of VSMC. These results demonstrate that endogenously produced ANP can exert autocrine and paracrine inhibitory effects on endothelial cell and VSMC growth. In vivo gene transfer of ANP may provide us with the opportunity of gene therapy for vascular diseases in which the abnormalities are vasoconstriction and pathological growth. (J. Clin. Invest. 1994. 94:824-829.) Key words: gene therapy • coculture • vascular tissues - growth inhibitory factor - Sendai virus (HVJ: hemagglutinating virus of Japan)

Address correspondence to Victor J. Dzau, M.D., Falk Cardiovascular Research Center, 300 Pasteur Drive, Stanford, CA 94305-5246.

Received for publication 29 September 1993 and in revised form 25 February 1994

J. Clin. Invest.

(C) The American Society for Clinical Investigation, Inc.

0021-9738/94/08/0824/06 $\$ 2.00$

Volume 94, August 1994, 824-829

\section{Introduction}

Atrial natriuretic peptide (ANP) ${ }^{1}$ was the first member of a family of natriuretic peptides isolated. It is highly abundant in the atria of the heart where its mRNA constitutes $\sim 2 \%$ of the total mRNA (1-4). ANP mRNA, albeit present at lower levels, has also been found in multiple tissues including hypothalamus, pituitary, aortic arch, lung, adrenal, and kidney $(5,6)$. This family of peptides exerts direct actions on the renal tubules, resulting in natriuretic and diuretic actions (1-4). In addition, these peptides also regulate sodium and water homeostasis indirectly via changes in glomerular filtration rates and inhibition of renin release and of aldosterone secretion (1-4). Moreover, ANP has been shown to be a direct smooth muscle relaxant. Furthermore, it is becoming apparent that these factors may also be potent regulators of growth. We and others have shown that ANP antagonizes the growth promoting effects of Ang II, serum, and purified growth factors on vascular smooth muscle cells (VSMC) and endothelial cells in vitro (7-9). This effect is in part mediated by the guanyl cyclase-linked receptors.

Vascular remodeling plays an important role in the pathophysiology of atherosclerosis, restenosis, and hypertension (1012). Remodeling is mediated in part by the growth of VSMC. The growth of VSMC is controlled by a balance of growth inhibitors and growth promoters and, in the normal adult vessel, this balance results in a very low rate of growth of the smooth muscle. However, after vascular injury by either mechanical or biochemical means, this balance is shifted such that proliferation of the smooth muscle cells occurs $(10-12)$. The identity of the factors that regulate this growth is the subject of intense investigation and to date is not fully understood. However, it is becoming increasingly apparent that among the many factors that may influence vascular structure, vasoactive substances may play a major role.

To examine the possible function of local expression of ANP in the vascular tissues, we examined the biochemical and physiological effects of overexpression of ANP gene on endothelial cells and the inhibitory action of overexpressed ANP gene against VSMC growth. We previously reported the highly efficient and nontoxic gene transfer method using Sendai virus (HVJ; Hemagglutinating Virus of Japan) in cultured VSMC $(13,14)$. Here, we extended its usefulness to gene transfer into cultured endothelial cells and VSMC. Our data demonstrate that increased ANP expression in endothelial cells and VSMC can

1. Abbreviations used in this paper: ANP, atrial natriuretic peptide; BSS, balanced salt solution; DSF, defined serum-free medium; HMG, high mobility group; HVJ, hemagglutinating virus of Japan; NEP, neutral endopeptidase; VSMC, vascular smooth muscle cells. 
result in decreased DNA replication under the basal and stimulated conditions.

\section{Methods}

Construction of plasmids. To produce an ANP expression vector, an Xhol fragment containing rat ANP cDNA (kindly provided by Dr. Matsuo, National Institute of Cardiovascular Disease, Osaka, Japan) was inserted into the XhoI site of pUC-CAGGS expression vector plasmid (kindly provided by Junichi Miyazaki, Tokyo University, Tokyo, Japan). In this plasmid, transcription of the ANP cDNA was under the control of the chicken beta-actin promoter and the cytomegalovirus enhancer. Previous studies in our laboratory have established that this expression vector produces high transcript levels in vascular cells for sustained periods both in vitro and in vivo (13-16).

Cell culture. Bovine aortic endothelial cells (passages 3-7) were maintained in DME medium with $10 \%$ calf serum, $100 \mathrm{U} / \mathrm{ml}$ penicillin, and $100 \mathrm{mg} / \mathrm{ml}$ streptomycin. Rat aortic smooth muscle cells from 3mo-old Wistar-Kyoto rats (passages 17-20) were maintained in Waymouth's medium (Gibco, Grand Island, NY) with 5\% calf serum, 100 $\mathrm{U} / \mathrm{ml}$ penicillin, and $100 \mathrm{mg} / \mathrm{ml}$ streptomycin. Cells were incubated at $37^{\circ} \mathrm{C}$ in a humidified atmosphere of $95 \%$ air $-5 \% \mathrm{CO}_{2}$ with media changes every $2 \mathrm{~d}$.

Preparation of HVJ-liposomes. We have previously reported the high efficiency transfection of cells in culture using Hemagglutinating Virus of Japan (HVJ)-coated liposomes (13-16). Briefly, phosphatidylserine, phosphatidylcholine, and cholesterol were mixed in a weight ratio of 1:4.8:2 in tetrahydrofuran. The lipid mixture $(10 \mathrm{mg})$ was deposited on the sides of a flask by removal of the solvent in a rotary evaporator. $96 \mu \mathrm{g}$ of high mobility group (HMG) 1 nuclear protein, purified from calf thymus, was mixed with plasmid $300 \mu \mathrm{g}$ DNA in $200 \mu \mathrm{l}$ of balanced salt solution (BSS; $137 \mathrm{mM} \mathrm{NaCl}, 5.4 \mathrm{mM} \mathrm{KCl}, 10 \mathrm{mM}$ Tris$\mathrm{HCl}, \mathrm{pH}$ 7.6) at $20^{\circ} \mathrm{C}$ for $1 \mathrm{~h}$, and then added to the dried lipid. Liposome-DNA-HMG 1 complex suspension was mixed by vortex, sonication for $3 \mathrm{~s}$, and shaking for $30 \mathrm{~min}$. Purified HVJ (Z strain) was inactivated by ultraviolet (UV) irradiation $\left(110 \mathrm{erg} / \mathrm{mm}^{2}\right.$ per s) for $3 \mathrm{~min}$ immediately before use. The liposome suspension $(0.5 \mathrm{ml}$, containing 10 $\mathrm{mg}$ of lipids) was mixed with HVJ (20,000 hemagglutinating units) in a total volume of $4 \mathrm{ml}$ of BSS. The mixture was incubated at $4^{\circ} \mathrm{C}$ for $10 \mathrm{~min}$ and then for $30 \mathrm{~min}$ with gentle shaking at $37^{\circ} \mathrm{C}$. Free HVJ was removed from the $\mathrm{HVJ}$-liposomes by sucrose density gradient centrifugation. The top layer of the sucrose gradient containing the HVJ-liposome-DNA complex was collected and used immediately.

Transfection of cultured vascular cells. $1 \times 10^{6}$ endothelial cells or VSMC were seeded onto six-well plates and grown to $80 \%$ confluence. Cells were washed three times with BSS containing $2 \mathrm{mM} \mathrm{CaCl}_{2}$ and then incubated with $1 \mathrm{ml}$ of $\mathrm{HVJ}$-liposomes-DNA complex ( $2.5 \mathrm{mg}$ of lipids and $10 \mu \mathrm{g}$ of encapsulated DNA) at $4^{\circ} \mathrm{C}$ for $5 \mathrm{~min}$ followed by $37^{\circ} \mathrm{C}$ for $30 \mathrm{~min}$ (total, $35 \mathrm{~min}$ ). The cells were then washed and fed fresh medium containing $10 \%$ calf serum and placed into the $\mathrm{CO}_{2}$ incubator.

Measurement of ANP concentration in endothelial cells. To document successful transfection of the cells, we examined the production of ANP. $24 \mathrm{~h}$ after transfection, the medium was changed and the cells were incubated for an additional $48 \mathrm{~h}$. After washing with PBS twice, cells were mechanically scraped, boiled for $7 \mathrm{~min}$ in $0.1 \mathrm{M}$ acetic acid containing $0.1 \%$ Triton $\mathrm{X}-100$, and disrupted by sonication. The cell homogenates were centrifuged at $10,000 \mathrm{~g}$ for $30 \mathrm{~min}$ at $4^{\circ} \mathrm{C}$ and the supernatants were stored at $-20^{\circ} \mathrm{C}(17)$.

To study the release of ANP, transfected cells ( $48 \mathrm{~h}$ after transfection) were washed and fed with $1 \mathrm{ml}$ of defined serum-free (DSF) medium containing media supplemented with $5 \times 10^{-7} \mathrm{M}$ insulin, $5 \mathrm{mg} / \mathrm{ml}$ transferrin, and $0.2 \mathrm{mM}$ ascorbate (18). $24 \mathrm{~h}$ later, conditioned medium was collected, centrifuged at $600 \mathrm{~g}$ for $10 \mathrm{~min}$, and stored at $-20^{\circ} \mathrm{C}$ (17).

RIA for immunoreactive ANP was performed (Amersham, Arlington Heights, IL). The antibody against ANP cross-reacts with rat alphaANP (70\%) and rat ANP 8-33 (95\%) but not with other fragments of rat ANP, BNP, or CNP.
Determination of DNA synthesis. Endothelial cells and VSMC were seeded onto 24-well tissue culture plates. At confluence, cells were washed three times with BSS containing $2 \mathrm{mM} \mathrm{CaCl}_{2}$, and then incubated with $500 \mu \mathrm{l}$ of $\mathrm{HVJ}$-liposomes $(1.3 \mathrm{mg}$ of lipids and $5 \mu \mathrm{g}$ of encapsulated DNA). The cells were incubated at $4^{\circ} \mathrm{C}$ for $5 \mathrm{~min}$ and then at $37^{\circ} \mathrm{C}$ for $30 \mathrm{~min}$. The solution was then changed to fresh medium containing serum and the cells were incubated overnight in a $\mathrm{CO}_{2}$ incubator. The cells were then rendered quiescent by incubation for $60 \mathrm{~h}$ in DME with $0.5 \%$ calf serum. Relative rates of DNA synthesis were assessed by determination of tritiated thymidine incorporation into TCAprecipitable material over the next $24 \mathrm{~h}$. In some experiments, the effects of exogenously added ANP $\left(10^{-7} \mathrm{M}\right)$ were examined. ANP or vehicle was added $12 \mathrm{~h}$ before the addition of tritiated thymidine. $24 \mathrm{~h}$ after the addition of thymidine, the cells were washed twice with cold PBS, twice with $10 \%$ (wt/vol) cold TCA, and incubated with $10 \%$ TCA at $4^{\circ} \mathrm{C}$ for $30 \mathrm{~min}$. Cells were rinsed in $95 \%$ ethanol and dissolved in 0.25 $\mathrm{N} \mathrm{NaOH}$ at $4^{\circ} \mathrm{C}$ for $3 \mathrm{~h}$, neutralized, and the radioactivity was determined by liquid scintillation spectrometry $(7,8)$.

The rates of DNA synthesis were similarly examined in transfected VSMC rendered quiescent by growth in DSF for $48 \mathrm{~h}$. At this point, $10^{-6} \mathrm{M}$ Ang II, $20 \mathrm{ng} / \mathrm{ml}$ PDGF, 5\% calf serum, or vehicle was added for an additional $12 \mathrm{~h}$ before the addition of tritiated thymidine. Cells were harvested $24 \mathrm{~h}$ later.

Effect of conditioned medium on cellular growth and cGMP content. The ability of the conditioned media to induce increases in endothelial cell cyclic GMP was performed as previously described $(7,8,17)$. The test endothelial cells were washed twice in serum-free DME and then preincubated at $37^{\circ} \mathrm{C}$ for 15 min with fresh DME containing $0.5 \mathrm{mM}$ isobutylmethylxanthine (Sigma Chemical Co., St. Louis, MO). Conditioned medium collected from endothelial cells transfected with either the ANP expression vector or the control vector diluted 1:1 with fresh medium and added to the test cells. After $15 \mathrm{~min}$ of incubation, the medium was removed, $1 \mathrm{ml}$ ice-cold $6 \%$ TCA was-added, and the cells were harvested by scrapping. Samples were centrifuged to remove precipitated proteins, and the supernatant fractions were extracted three times with water-saturated ether. Cyclic GMP was measured with a radioimmunoassay kit (Amersham) after succinylation $(7,8)$.

The ability of the conditioned media to block DNA synthesis in a paracrine fashion was also examined. Conditioned medium, collected from endothelial cells transfected with the ANP expression vector or a control vector as described above, was diluted 1:1 with fresh media. Quiescent VSMC (seeded to six-well plate and placed in DSF for $48 \mathrm{~h}$ after confluence) were treated with the diluted conditioned media. In some wells, Ang II was added to stimulate DNA synthesis. $12 \mathrm{~h}$ later, tritiated thymidine was added and the cells were harvested $24 \mathrm{~h}$ later.

Coculture. Endothelial cells were seeded onto cell culture inserts $(0.45 \mu \mathrm{M}$ pore size; Costar Corp., Cambridge, MA) and were grown in DME with $10 \%$ calf serum. VSMC were seeded onto six-well plates and maintained in Waymouth's medium with $5 \%$ calf serum. At $80 \%$ confluence, HVJ-liposome-DNA complex containing the control vector or the ANP expression vector (DNA $10 \mu \mathrm{g}$ in liposome) was incubated for $5 \mathrm{~min}$ at $4^{\circ} \mathrm{C}$ and for $30 \mathrm{~min}$ at $37^{\circ} \mathrm{C}$. $2 \mathrm{~d}$ after transfection, the inserts containing the transfected endothelial cells were put into the wells containing the quiescent VSMC. For $24 \mathrm{~h}$, coculture of endothelial cells with VSMC was incubated in Waymouth's medium with $0.5 \%$ calf serum and pulsed with $\left[{ }^{3} \mathrm{H}\right]$ thymidine for $12 \mathrm{~h}(24-36 \mathrm{~h}$ after coculture). Relative rates of DNA synthesis were assessed by determination of tritiated thymidine incorporations into TCA-precipitable material.

Materials. Ang II, fibroblast growth factor (FGF), PDGF, and thiorphan were obtained from Sigma Chemical Co.

Statistical analysis. All values are expressed as mean \pm SEM. All experiments were repeated at least three times. Analysis of variance with subsequent Duncan's test was used to determine differences in multiple comparisons. $P<0.05$ was considered statistically significant.

\section{Results}

ANP expression in transfected endothelial cells. Endothelial cells transfected with the ANP expression vector synthesized 

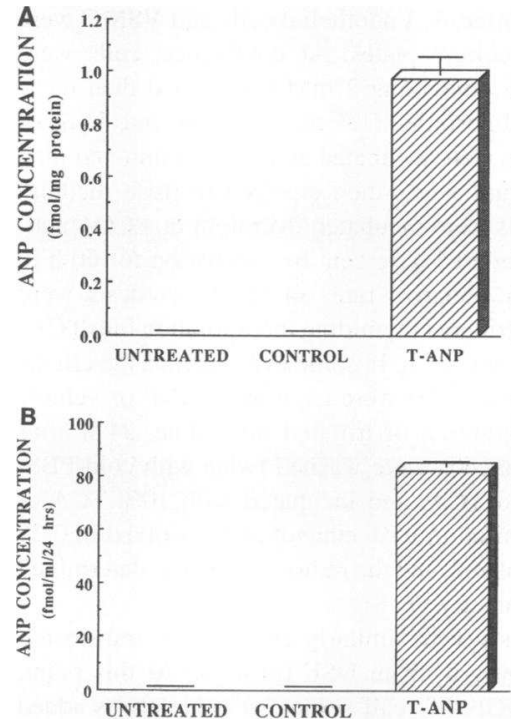

Figure 1. RIA of immunoreactive ANP in cultured endothelial cells $(A)$ and culture medium (B) after transfection of ANP or control vector. $n$ $=5$ per group. $U N$ TREATED, untreated cells; CONTROL, cells transfected with control vector; $T$-ANP, cells transfected with ANP vector. $P<0.01$ vs. other groups. and secreted ANP. ANP was detected in homogenates of endothelial cells transfected with ANP expression vector, but not those from nontransfected cells or cells transfècted with control vector (Fig. $1 A$ ). The accumulation of immunoreactive ANP was also readily detected in conditioned medium from endothelial cells transfected with ANP expression vector (Fig. $1 B$ ), but not in conditioned medium from nontransfected cells or cells transfected with control vector.

To confirm the biological activity of the ANP assayed by RIA, we performed the cGMP bioassay experiment. We used endothelial cells as a bioassay system to assess the acute induction of cGMP levels in response to a brief exposure to ANP in conditioned medium. The incubation of confluent untreated endothelial cells with conditioned medium from the endothelial cells transfected with ANP expression vector resulted in a significant increase in endothelial cell cGMP level as compared with the effect of conditioned medium from the endothelial cells transfected with control expression vector $(0.789 \pm 0.044$ and $0.501 \pm 0.029 \mathrm{pmol} / \mathrm{mg}$ protein, respectively; $P<0.01$ ). These data document synthesis, secretion, and biological activity of the ANP transgene.

Autocrine effects of transfected ANP expression vector on DNA synthesis of confluent endothelial cells. The autocrine influence of transfection of ANP vector on DNA synthesis is shown in Fig. 2. Transfection of the endothelial cells with the control expression vector did not alter DNA synthesis compared with the basal rate in nontransfected endothelial cells (DNA synthesis; untreated endothelial cells: $8,740 \pm 2,134 \mathrm{c}$ vs. endothelial cells transfected with control vector: $8,626 \pm 1,440 \mathrm{cpm} /$ well, $P=$ NS). However, DNA synthesis in the endothelial cells transfected with ANP expression vector decreased significantly compared with that in the endothelial cells transfected with control expression vector. The inhibition of DNA synthesis in cells transfected with the ANP vector was comparable to that caused by exogenously added ANP $\left(10^{-7} \mathrm{M}\right)$. This inhibitory effect caused by transfected ANP vector was also found under FGF-stimulated conditions (Fig. $2 B$ ).

ANP is rapidly degraded by neutral endopeptidase (NEP). To examine if the effects of ANP expression could be increased by inhibition of NEP, we examined the effect of the NEP inhibi-

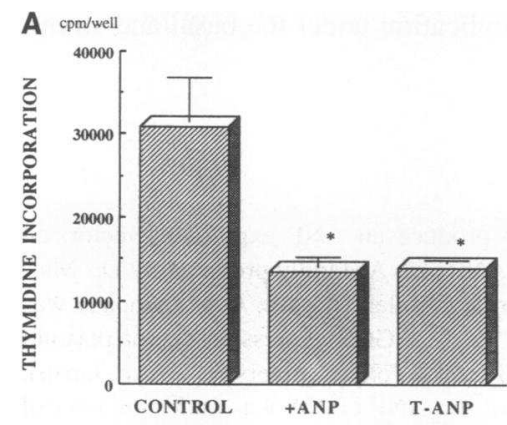

Figure 2. Inhibitory effect of transfected ANP cDNA on the incorporation of $\left[{ }^{3} \mathrm{H}\right]$ thymidine in cultured endothelial cells under basal $(A)$ and FGFstimulated $(B)$ conditions. (A) CONTROL, cells transfected with control vector; $T$-ANP, cells transfected with ANP vector. $n=5$ per group. $* P<0.01$ vs. CONTROL; (B) BASAL, no FGF addition; $+F G F$, FGF $(30 \mathrm{ng} / \mathrm{ml})$ added to transfected cells; $n=5$ per group. ${ }^{*} P<0.01$ vs. control vector.

tor thiorphan on DNA synthesis. The addition of $3 \times 10^{-7} \mathrm{M}$ thiorphan did not enhance the inhibitory effect of endogenously produced ANP to endothelial cells growth (Table I).

Paracrine effect of conditioned medium from endothelial cells on DNA synthesis of postconfluent VSMC. Incubation of quiescent VSMC with conditioned media collected from the endothelial cells transfected with the ANP expression vector resulted in a significant decrease in basal and Ang II-stimulated DNA synthesis compared with incubation with conditioned medium from the endothelial cells transfected with control expression vector (Fig. 3). As above, the addition of NEP inhibitor (3 $\times 10^{-7} \mathrm{M}$ thiorphan) did not enhance the inhibitory effect of conditioned medium from the endothelial cells transfected with ANP expression vector on VSMC DNA synthesis, as shown in Table II.

This inhibitory action of ANP could also be observed in coculture. Using coculture system, endothelial cells transfected with ANP vector significantly decreased DNA synthesis of quiescent nontransfected VSMC (control vector transfected: $81,121 \pm 4,389$ vs. ANP vector transfected: $64,564 \pm 3,055 \mathrm{cpm} /$ well; $P<0.01$ ). $10^{-6} \mathrm{M}$ Ang II increased VSMC DNA synthe-

Table I. Effects of ANP and NEP Inhibitor on Endothelial Cell Growth

\begin{tabular}{lc}
\hline & {$\left[{ }^{3} \mathrm{H}\right]$ Thymidine incorporation } \\
\hline Control & $14,921 \pm 131$ \\
T-ANP & $11,483 \pm 326^{*}$ \\
Control + NEPI & $13,910 \pm 270$ \\
T-ANP + NEPI & $10,586 \pm 291^{*}$ \\
\hline
\end{tabular}

Control, endothelial cells transfected with control vector; T-ANP, endothelial cells transfected with ANP vector; CONTROL + NEPI, thiophan $\left(3 \times 10^{-7} \mathrm{M}\right)$ added to endothelial cells transfected with control vector; T-ANP + NEPI, thiophan $\left(3 \times 10^{-7} \mathrm{M}\right)$ added to endothelial cells transfected with ANP vector; $n=5$ per group. ${ }^{*} P<0.01$ vs. control. 


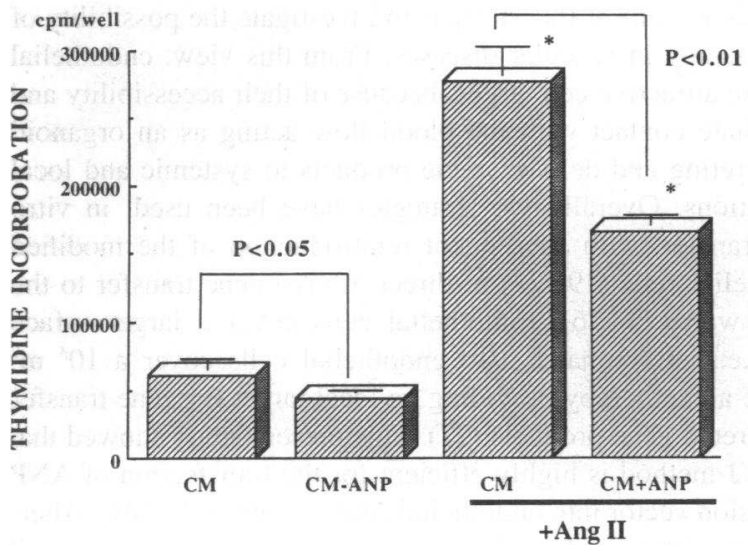

Figure 3. Inhibitory effect of conditioned media from endothelial cells on the incorporations of $\left[{ }^{3} \mathrm{H}\right]$ thymidine in VSMC. CM, VSMC incubated with conditioned medium collected from endothelial cells transfected with control vector; $C M-A N P$, VSMC incubated with conditioned medium collected from endothelial cells transfected with ANP vector; + Ang II, angiotensin II $\left(10^{-7} \mathrm{M}\right)$ added to transfected VSMC. $n=5$ per group. ${ }^{*} P<0.01$ vs. without Ang II.

sis. This effect was attenuated in VSMC transfected with ANP vector (addition of Ang II to VSMC transfected with control vector: $234,868 \pm 3,191$ vs. addition of Ang II to VSMC transfected with ANP vector $218,553 \pm 1,830 \mathrm{cpm} / \mathrm{well} ; P$ $<0.01)$.

Autocrine and paracrine effects of transfected ANP expression vector on DNA synthesis of postconfluent VSMC. We examined the autocrine/paracrine inhibitory effect of locally expressed ANP in VSMC. Transfection of VSMC with ANP expression vector also resulted in an autocrine inhibition of DNA synthesis. This effect was comparable to the effect of exogenously administered $10^{-7} \mathrm{M}$ ANP, as shown in Fig. 4. Ang II stimulated DNA synthesis of these VSMC dose dependently. This increase in DNA synthesis was also significantly inhibited by transfection of the cells with the ANP expression vector (Fig. 5). Incubation with conditioned medium from VSMC transfected with ANP expression vector also significantly de-

Table II. Effects of ANP and NEP Inhibitor on VSMC Growth

\begin{tabular}{lc}
\hline & cpm/well \\
& {$\left[{ }^{3} \mathrm{H}\right]$ Thymidine incorporation } \\
Control & $70,689 \pm 2,035$ \\
T-ANP & $57,973 \pm 6,093^{*}$ \\
Control + NEPI & $66,758 \pm 1,429$ \\
T-ANP + NEPI & $58,181 \pm 2,005^{*}$ \\
\hline
\end{tabular}

In this experiment, VSMC were incubated with conditioned medium collected from endothelial cells transfected with ANP or control vector. Control, conditioned medium collected from endothelial cells transfected with control vector; T-ANP, conditioned medium collected from endothelial cells transfected with ANP vector; Control + NEPI, thiorphan $\left(3 \times 10^{-7} \mathrm{M}\right)$ added to conditioned medium collected from endothelial cells transfected with control vector; T-ANP + NEPI, thiorphan $\left(3 \times 10^{-7} \mathrm{M}\right)$ added to conditioned medium collected from endothelial cells transfected with ANP vector. Each group contains five samples. $* P<0.01$ vs. control.

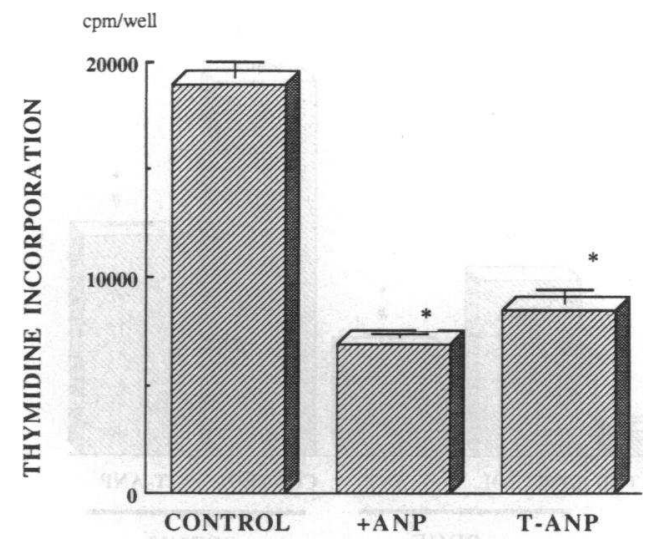

Figure 4. Inhibitory effect of transfected ANP cDNA on the incorporations of $\left[{ }^{3} \mathrm{H}\right]$ thymidine in cultured VSMC. CONTROL, cells transfected with control vector; $+A N P$, ANP $\left(10^{-7} \mathrm{M}\right)$ added to cells transfected with control vector; $T$-ANP, cells transfected with ANP vector. $\mathrm{n}=5$ per group. ${ }^{*} P<0.01$ vs. CONTROL.

creased DNA synthesis of quiescent confluent nontransfected VSMC (data not shown). Similarly, PDGF- or serum-stimulated VSMC growth was significantly inhibited by transfection of the cells with the ANP vector, as shown in Fig. 6.

\section{Discussion}

The family of natriuretic peptides exerts numerous actions throughout the cardiovascular system (1-4). Initially isolated on the basis of its natriuretic and diuretic properties, ANP has since been shown to inhibit renin and aldosterone release, to relax vascular smooth muscle, and to inhibit growth in endothelial cells and VSMC. ANP is synthesized in large amounts in the atria and secreted into the blood. However, ANP transcripts and immunoreactive peptide can also be found in numerous locations, including the aorta, kidney, and adrenal gland $(5,6)$. Moreover, a second member of this natriuretic family, CNP, has been shown to be expressed in endothelial cells (17). This has led to the speculation that locally synthesized ANP may influence local functions. However, this hypothesis has not been examined previously. In this report, we demonstrate that ANP synthesized in endothelial cells or VSMC is capable of exerting both paracrine and autocrine effects on the growth of these vascular cells.

The concept of the local control of vascular function by

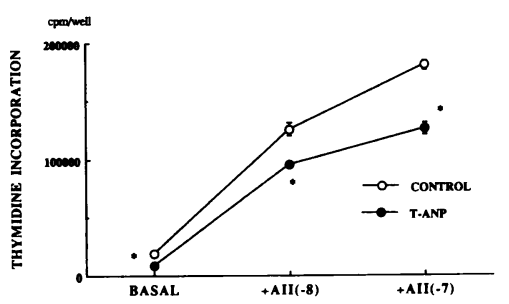

Figure 5. Inhibitory effect of transfected ANP cDNA on the incorporations of $\left[{ }^{3} \mathrm{H}\right]$ thymidine in cultured VSMC under Ang II stimulation. $B A S A L$, without Ang II; + AII $(-8)$, Ang II $\left(10^{-8}\right.$ $M)$ added to transfected VSMC; + AII $(-7)$, Ang II $\left(10^{-7} \mathrm{M}\right)$ added to transfected VSMC; $n$ $=5$ per group. $* P<0.01$ vs. control vector. 


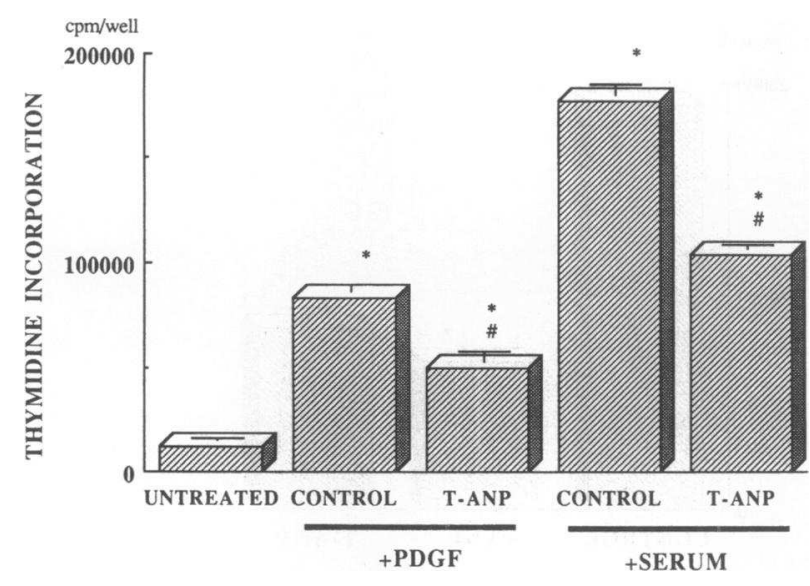

Figure 6. Inhibitory effect of transfected ANP cDNA on the incorporations of $\left[{ }^{3} \mathrm{H}\right]$ thymidine in cultured VSMC under PDGF and serum stimulation. UNTREATED, untreated cells; CONTROL, cells transfected with control vector; $T$-ANP, cells transfected with ANP vector; $+P D G F$, PDGF $(10 \mathrm{ng} / \mathrm{ml})$ added to transfected VSMC; +SERUM, 5\% serum added to transfected VSMC; $n=4$ per group. ${ }^{*} P<0.01$ vs. $U N$ TREATED; \#P $<0.01$ vs. CONTROL.

locally synthesized compounds has been recently described. For example, all the components of the renin angiotensin system have been reported to be present within the vasculature (13, 14). We and others have hypothesized that locally synthesized Ang II may play a major role in the regulation of both vascular tone and structure. Similarly, multiple endothelial-derived substances $\left(\mathrm{PGI}_{2}, \mathrm{NO}\right)$ also have profound influences on the vascular smooth muscle functions $(10,11)$. Moreover, after vascular injury, locally synthesized cytokines and growth factors contribute to the development of neointimal lesions $(19,20)$. These local systems appear to be independently regulated by regional factors and may play important physiological and pathophysiological roles. The findings that the natriuretic peptides are expressed in the vasculature (5) and the current findings that ANP may act in an autocrine/paracrine manner, supports the hypothesis that local ANP (and CNP) may regulate local function.

What is the importance of this local synthesis of the natriuretic peptides, especially in light of the abundant circulating levels? The expression of ANP in the vasculature is orders of magnitude lower than that observed in the atria. However, due to the limited extracellular volume within the vessel wall, low expression of ANP may result in high extracellular levels of the peptide. Moreover, the ability of the local tissues to respond to differences in local environment allows for the rapid regulation of local function.

To pursue these questions, we have examined the consequences of ANP expression in vascular cells in cell culture. Although ANP mRNA has been found in endothelial cells and smooth muscle cells in vivo (5), these cells in culture do not retain the ability to express the peptide. Of the multiple techniques available to direct the expression of proteins in cells in culture, we chose the HVJ-liposome-DNA complex methodology. Previously, we have demonstrated that this technique results in high efficiency of transfection with little or no toxic effects (13-16). This allows the examination of the effects on growth of transiently expressed proteins that would be difficult or impossible with other more toxic methods of DNA transfection.
Another aim of this study is to investigate the possibility of gene therapy in vascular diseases. From this view, endothelial cells are attractive cell targets because of their accessibility and immediate contact with the blood flow acting as an organoid for secreting and delivery gene products to systemic and local circulations. Overall, two strategies have been used: in vitro gene transfer, with subsequent reintroduction of the modified endothelial cells (19-22) or direct in vivo gene transfer to the vessel wall (23-26). Endothelial cells cover a large surface area, i.e., an estimated $10^{12}$ endothelial cells cover a $10^{3} \mathrm{~m}^{2}$ surface area, thereby providing an ideal target for gene transfer for secreted gene products (27). This present study showed that the HVJ method is highly efficient for the transfection of ANP expression vector into endothelial cells as well as VSMC. Alternatively, with regards to direct gene transfer into the vessel wall as further gene therapy strategy, we also examined the direct transfer of ANP vector to the endothelial cells and VSMC in vitro. Endothelial cells and VSMC directly transfected with ANP expression vector exhibited the decreases in DNA synthesis under the basal and stimulated conditions in an autocrine/ paracrine manner.

Inhibitory growth effects of ANP transfection may be due in part to an increased cellular cGMP content. Previously we documented that the exogenous administration of ANP inhibited VSMC and endothelial cell growth in association with cGMP accumulation and that this growth inhibitory effect was mimicked by stable cGMP analogues $(7,8)$. However, the causal relationship between acute elevations in cGMP and long-term growth effects remains to be further defined. In the present study, we assayed cGMP levels as an endogenous bioassay to verify the biological activity of secreted protein produced by the ANP transgene. In our data there is an apparent discrepancy between the modest increase in cGMP content after a brief exposure to exogenous ANP and the magnitude of thymidine incorporation inhibition induced by prolonged exposure to conditioned medium from transfected cells. There are several explanations for this apparent discrepancy. The pronounced effect of autocrine ANP production on cell growth reflects the cumulative effect of continuous biosynthesis and chronic exposure to ANP. In contrast, we used a different set of endothelial cells as a bioassay system to assess the acute induction of cGMP levels in response to a brief exposure to ANP diluted in conditioned medium. Clearly, the short-term rise of cGMP in response to exogenous ANP does not reflect the cGMP accumulation after prolonged exposure to autocrine ANP. It is also well established that endothelial cells express clearance receptors (28) and that the acute biological response may be diminished in the presence of unoccupied clearance receptors. In contrast, chronic exposure to ANP may allow saturation of the clearance receptors and relative enhancement of biological effects such as the inhibition of cell growth.

The apparent discrepancy may also reflect the fact that after $24 \mathrm{~h}$ in contact with the well-described cellular peptidases, the partially degraded ANP continues to be recognized by the RIA but has lost some biological activity. In contrast, transfected cells are continuously exposed to newly synthesized autocrine ANP before significant peptidase degradation, thereby resulting in a more pronounced biological effect. Moreover, it is conceivable that the growth inhibitory effects of ANP are also mediated by pathways not reflected in steady state cGMP accumulation. There are a variety of signal transduction pathways by which ANP may influence growth independent of the absolute level 
of cGMP, e.g., calcium ion fluxes, cAMP, and tyrosine kinase activity. In addition, it is well established that ANP may have indirect effects on cell growth by modulating the production of autocrine growth factors or their receptors (29). It is therefore plausible that the magnitude of the cGMP levels will not precisely correlate with the magnitude of the growth response to autocrine ANP.

In this study we used ANP expression vector that was driven by the chicken beta-actin promoter and cytomegalovirus enhancer. As described previously, this construct can result in the expression of the high levels of transcripts for a sustained period in vitro and in vivo $(13,14,28)$. We previously showed that HVJ method can transfect genes efficiently into the intact (uninjured) and injured rat carotid arteries in vivo (26). Furthermore, the expression of transferred gene appears to be higher in the injured vessels. Therefore, direct gene transfection of ANP vector into artery is an alternative possibility for in vivo gene therapy. It is unclear if the degree of inhibition obtained by ANP gene transfer observed in this study is sufficient to suppress pathological VSMC proliferation in vivo. Judging from our previous work using antisense oligonucleotides against cell cycle regulatory genes, the dose that resulted in $50 \%$ inhibition of VSMC growth in vitro resulted in $40-50 \%$ inhibition of neointima formation after balloon injury in vivo (30). As the present study showed $50 \%$ inhibition in VSMC growth in vitro, in vivo transfer of ANP vector might be sufficient to inhibit VSMC accumulation in vivo. However, further studies are needed to apply this ANP transfection strategy for in vivo gene therapy.

\section{Acknowledgments}

We thank Dr. Jitsuo Higaki for technical advice, Wendy Lee for excellent technical assistance, and Melinda Hing for preparing the manuscript.

This work is supported by National Institutes of Health grants HL35610, HL-35252, HL-42663, and the University of California TobaccoRelated Disease Program 1RT215. Dr. Morishita is the recipient of a fellowship from the American Heart Association, California Affiliate. Gary H. Gibbons is the recipient of a Robert Wood Johnson Minority Faculty Development Award.

\section{References}

1. Nakao, K., H. Itoh, S. Suga, Y. Ogawa, and H. Imura. 1993. The natriuretic peptide family. Curr. Opin. Neph. Hypertens. 2:45-50.

2. Nakao, K., S. Suga, Y. Ogawa, H. and H. Imura. 1992. Molecular biology and biochemistry of the natriuretic peptide system I: natriuretic peptides. J. Hypertens. 10:907-912.

3. Nakao, K., S. Suga, Y. Ogawa, and H. Imura. 1992. Molecular biology and biochemistry of the natriuretic peptide system II: natriuretic peptide receptors. $J$. Hypertens. 10:1111-1114.

4. Rosenzweig, A., and C. E. Seidman. 1991. Atrial natriuretic factor and related peptide hormones. Annu. Rev. Biochem. 60:229-255.

5. Gardner, D. G., C. F. Deschepper, and J. D. Baxter. 1987. The gene for the atrial natriuretic factor is expressed in the aortic arch. Hypertension (Dallas). 19:103-106.

6. Daginino, L., J. Drouin, and J. Nemer. 1991. Differential expression of natriuretic peptide genes in cardiac and extracardiac tissues. Mol. Endocrinol. 5:1292-1300.

7. Itoh, H., R. E. Pratt, and V. J. Dzau. 1990. Atrial natriuretic polypeptide inhibits hypertrophy of vascular smooth muscle cells. J. Clin. Invest. 86:16901697.

8. Itoh, H., R. E. Pratt, M. Ohno, and V. J. Dzau. 1992. Atrial natriuretic polypeptide as a novel antigrowth factor of endothelial cells. Hypertension (Dallas). 19:758-761.

9. Abell, T. J., A. M. Richards, H. Ikram, E. A. Espiner, and T. Yandle. 1989. Atrial natriuretic factor inhibits proliferation of vascular smooth muscle cells stimulated by platelet-derived growth factor. Biochem. Biophys. Res. Commun. 160:1392-1396.

10. Dzau, V. J. 1993. The role of mechanical and humoral factors in growth regulation of vascular smooth muscle cells and cardiac myocytes. Curr. Opin. Neph. Hypertens. 2:27-32.

11. Dzau, V. J., and G. H. Gibbons. 1991. Endothelium and growth factors in vascular remodeling of hypertension. Hypertension (Dallas). 18(Suppl III):III115-III-121.

12. Krieger, J. E., and V. J. Dzau. 1991. Molecular biology of hypertension. Hypertension (Dallas). 18:I-3-I-17.

13. Morishita, R., G. H. Gibbons, Y. Kaneda, T. Ogihara, and V. J. Dzau. 1993. Novel and effective gene transfer method for study of vascular renin angiotensin system. J. Clin. Invest. 91:2580-2585.

14. Morishita, R., G. H. Gibbons, Y. Kaneda, T. Ogihara, and V. J. Dzau. 1993. Novel in vitro gene transfer method for study of local modulators in vascular smooth muscle cells. Hypertension (Dallas). 21:894-899.

15. Kaneda, Y., K. Iwai, and T. Uchida. 1989. Increased expression of DNA co-introduced with nuclear protein in adult rat liver. Science (Wash. DC). 243:375-378.

16. Kaneda, Y., K. Iwai, and T. Uchida. 1989. Introduction and expression of the human insulin gene in adult rat liver. J. Biol. Chem. 264:12126-12129.

17. Suga, S., K. Nakao, H. Itoh, Y. Komatsu, Y. Ogawa, N. Hama, and H. Imura. 1992. Endothelial production of C-type natriuretic peptide and its marked augmentation by transforming growth factor-beta. Possible existence of " vascular natriuretic peptide system." J. Clin. Invest. 90:1145-1149.

18. Owens, G. K., and L. G. Thompson. 1986. Expression of smooth muscle specific isoactin in cultured smooth muscle cells. Relationship between growth and cytodifferentiation. J. Cell Biol. 102:343-352.

19. Lynch, C. M., M. M. Clowes, W. R. A. Osborne, A. W. Clowes, and A. D. Miller. 1992. Long-term expression of human adenosine deaminase in vascular smooth cells of rats: a model for gene therapy. Proc. Natl. Acad. Sci. USA 89:1138-1142.

20. Nabel, E., G. Plautz, F. M. Boyce, J. C. Stanley, and G. J. Nabel. 1989. Recombinant gene expression in vivo within endothelial cells of the arterial wall Science (Wash. DC). 244:1342-1344.

21. Wilson, J. M., L. K. Birinyl, R. N. Salomon, P. Libby, A. D. Callow, and R. C. Mulligan. 1989. Implication of vascular grafts lined with genetically modified endothelial cells. Science (Wash. DC). 244:1344-1346.

22. Dichek, D., R. F. Neville, J. A. Zwiebel, S. M. Freeman, M. B. Leon, W. and $\mathrm{F}$. Anderson. 1989. Seeding of intravascular stents with genetically engineered endothelial cells. Circulation. 80:1347-1353.

23. Nabel, E. G., G. Plautz, and G. J. Nabel. 1990. Site-specific gene expression in vivo by direct gene transfer into the arterial wall. Science (Wash. DC) 244:1285-1288.

24. Lemarchand, P., M. Jones, I. Yamada, and R. G. Crystal. 1993. In vivo gene transfer and expression in normal uninjured blood vessels using replicationdeficient recombinant adenovirus vectors. Circ. Res. 72:1132-1138.

25. Flugelman, M. Y., M. T. Jaklitsch, K. D. Newman, W. Casscells, G. L. Bratthauer, and D. A. Dichek. 1992. Low level in vivo gene transfer into the arterial wall through a perforated balloon catheter. Circulation. 85:1110-1117.

26. Morishita, R., G. H. Gibbons, L. Zhang, Y. Kaneda, T. Ogihara, and V. J. Dzau. 1992. In vivo gene transfer into intact blood vessels: a novel and efficient method. Circulation 86:I-227. (Abstr.)

27. Machovich, R. 1988. Biology of endothelial cells. In Blood Vessel Wal and Thrombosis. Vol. 1. R. Machovich, editor. CRC, Boca Raton, FL. 115-140.

28. Suga, S., K. Nakao, M. Mukoyama, H. Arai, K. Hosoda, Y. Ogawa, and H. Imura. 1992. Characterization of natriuretic peptide receptors in cultured cells. Hypertension (Dallas). 19:762-765

29. Kohno, M., K. Yokokawa, T. Horio, K. Yasunari, K. Murakawa, and T. Takeda. 1992. Atrial and brain natriuretic peptides inhibit the endothelin-1 secretory response to angiotensin II in porcine aorta. Circ. Res. 70:241-247.

30. Morishita, R., G. H. Gibbons, K. E. Ellison, M. Nakajima, L. Zhang, Y. Kaneda, T. Ogihara, and V. J. Dzau. 1993. Single intraluminal delivery of antisense cdc 2 kinase and PCNA oligonucleotides results in chronic inhibition of neointimal hyperplasia. Proc. Natl. Acad. Sci. USA. 90:8474-8479. 